\title{
The Analysis of Student's Writing Abilities of Kanji at Japanese Education Study Program of UNP
}

\author{
Nova Yulia \\ Japanese Education Study Program \\ Universitas Negeri Padang \\ Padang, Indonesia \\ nova_nihongo@yahoo.co.id
}

\begin{abstract}
The background of this research is the importance of masteringKanji in learning Japanese since most Japanese transcriptions use it. However, the large number of Kanjicharacters makes it difficult for the students to understand it. This research is done due to the importance of mastering Kanji for Japanese language learners since almost all writings in Japanese use it. Kanji is one of the most difficult aspects for Japanese language learners especially for those who do not have a cultural background about it. This happens since they are targeted to be able to master 1945 Kanji characters. In addition, one Kanji character has more than one pronunciation. Thus, they find it difficult to memorize and use those characters. A big number of characters and the various ways of writing as well as pronouncing them make the students difficult in mastering KanjiThe objective of this researchis to find out the Kanji mastery level ofthe $5^{\text {th }}$ semester students who are majoringthe Japanese Education in the academic yearof 2015/2016. This quantitative research applied the descriptive method. The subject was 19students of the study program. To select this sample, the purposive sampling technique was used. Data were taken fromthe scores of the students' Kanjitest. The instrument of the research was an essay test which measures the students' abilities in writing the Kanjicharacters. Based on the research results, it isfound that the students' mastery was in the "satisfactory" classification with scoreof 63,33.
\end{abstract}

Keywords - Kanji, students' writing abilities

\section{INTRODUCTION}

Characters in Japanese are called moji (文字). There are two types of moji (文字):Hyoui Moji (表意文字) and Hyouon Moji (表表表音). Hyoui Moji expresses content and meanings as well as states pronunciation. One type of Hyoui Moji isKanji (漢字). Meanwhile, Hyouon Moji states forms of pronunciation whichare meaningless (Zalman, 2014: 1). Hiragana(平仮名), Katakana(片仮名) and Romaji (ローマ字) or Latin characters are included in Hyouon Moji. It is inferred that Japanese characters consist of Kanji, Hiragana, Katakana, and Romajiwhich are later divided into two groups based on their use.

Sudjianto (2009: 71) states that Kana characters (Hiragana and Katakana) are included in Honsetsu Moji (本節文字) since the characters denote a meaningless syllable. However, there are several Japanese words consisting of only one syllable like particles and nouns such as え (e: picture), き (ki: tree), け (to: feather), and $て$ (te: hand). Those nouns also have their own Kanji likeえ (絵), き (木), け (毛), and て (手). It is said that Kana states a syllable which forms the pronunciation in Japanese.

Kanjicontains meanings and forms of pronunciation. It derives from Chinese characters which are adapted into Japanese. Sudana (Zalman, 2014: 14) explains that from its first entry into Japan (5th century) to the 9th century, Kanji is used in various ways such as translating and writing even though there are still problems in terms of sentence patterns as well as its pronunciation. The pronunciation of Kanjiin Japanese Kokkun (国訓) and Chinese Kasha (仮借) or using only Kanji produces the same sound (Kasha).

In 1981, a list of TouyouKanjiHyo (当用漢字表) was published and it contained 1945 Kanji consisting of 1850 characters in TouyouKanji and 95 Kanjirelated to legislation, documents, newspapers, magazines, and everyday life. The list contains Chinese or on yomi (音読み) and Japanese or kunyomi(訓読み) fonts and pronunciation forms. Since the number of Kanji is various and one character has more than one pronunciation, there have been some difficulties inmemorizing and using it.

Japanese students are targeted to be able to master the 1945 Kanji listed in the TouyouKanji based on their conditions and needs (Zalman; 2014: 15). In addition, foreign students are also expected to master 14 Kanjicharacters related to names of places, 17 Kanji characters used for writing names, and 24 other Kanji characters. Thus, there are 2000 Kanjicharacters that have to be mastered by them. Akihiko (Sudjianto, 2009: 58) divides several levels and time allocations in teaching Kanji. The first is the basic level in which 400-500 Kanjicharacters are learned within 13 weeks. The second is the intermediate level in which 700- 
800 Kanji characters are learned within 18 weeks. The last is the advanced level in which 300-400 Kanji characters are learned within 9 weeks. To sum up, according to Akihiko,the total number of Kanjicharacters that has to be mastered by foreign students is 1400 to 1700 .

Kanji is assumed to be one of the most difficult aspects for Japanese learners especially for those who have no cultural background related to the characters themselves. Surprisingly, Sudjianto (2009: 56) mentions that it is not only those who do not have the cultural background that find it difficult to learn Kanji. Even, students who possess such background such as Chinese, Korean and Taiwanese, still find it difficult to comprehend the Kanji characters. Although the Kanji characters that they use have the same forms and meanings, the way of pronouncing them is different. Therefore,pronunciation is one of the difficulties for the two types of students who learn about the Kanji characters.

Another difficulty faced by the students in the mastery of Kanji is the forms and manners of writing in Kanji. The result of a preliminary interview done by the researcher to the students of Japanese Education Study Program atUniversitasNegeri Padang shows that it is difficult for them to memorize the forms and write the Kanji characters themselves. The large number of characters as well as the rules in writing Kanjiare two factors which cause the difficulties.

The elements of forming Kanjiare as follows.

a) Bushu

Kanji is written out of several lines or streaks. The lines or streaks form parts of Kanjiandlater form a complete one (Sudjianto, 2009: 59). Those lines or streaks are called Bushu. Sudana(Zalman, 2014: 15) states that Kanjicontains Bushu which forms theKanji itself. Thus, Kanjiconsists of characters that form a letter out of lines. There are seven types of BushuKanji. They are:

(a) Hen 偏, which is a Bushu located on the left side of aKanji.

(b) Tsukuri旁, which is aBushu that is on the right side of a Kanji.

(c) Kanmuri冠, whichis theBushu located at the top of a Kanji.

(d) Ashi脚,whichis the Bushu located at the bottom of a Kanji.

(e) Tare 垂,whichis a Bushu shaped like a 90-degree angle from the top right to the top left.

(f) Nyoo饒,whichis a Bushushaped like a 90-degree angle from the left to the right.

(g) Kamae構, which is a Bushu that looks as if it surrounds other parts ofKanji.

Kanjiis grouped based on Bushuin order to find out the meaning of it. However, there are some of them that cannot be classified into thoseBushusince the forms are intact and they already have certain meanings. The examples are 心, 手, 生, 長, 飛, and so on. Therefore, not all Kanji can be put into the seven Bushu.

b) Kakusuu

The lines or streaks that make upKanji are usually counted. That number is called the Kakusuu (Sudjianto, 2009: 63). The number of lines varies. Some Kanji are formed from small lines while othersare formed out of many complicated lines or streaks. Similar to Bushu, Kakusuu is also used to search for a Kanji in a dictionary, KokugoJiten, and so on. Therefore, each Kanji dictionary will be equipped with Bushu and Kakusuu to help the students. There are various numbers of KakusuuKanji. At least, one Kanji has one streak. Meanwhile, the complicated one may have a large number of streaks.

The followings are the examples of Kakusuu on a Kanji:

二 (1 streak)
二, 人 (2 streaks)
土, 夕 (3 streaks)
今, 五 (4 streaks)
兄, 北 (5 streaks)
交, 合 (6 streaks)
位, 体 (7 streaks)
京, 参 (8 streaks)
乗, 前 (9 streaks)
俺, 座 (10 streaks)
動, 問 (11 streaks)
傘, 喜 (12 streaks)
塩, 夢 (13 streaks)
聞, 語 (14 streaks)
篂, 駒 (15 streaks)
頭, 親 (16 streaks)


Not only Bushu, Kanji also has Kakusuu. Each Kanji has a various number of streaks. To find out the number of streaks on a Kanji, the first step is to figure out the basics or steps in writing Kanji. If someone does not know the basic steps of writing $K a n j i$, it will be difficult for him/her to calculate the number of streaksin it. Errors in calculating the Kakusuuwill cause problems in determining a Kanji. As an example, Kanji月 (tsuki) has four streaks. However, without knowing the steps of writing, it seems like it has five streaks or more.

c) Hitsujun

The step or sequence in writing Kanjiis called Hitsujun. The writing of Kanjihas to be in order according to the correct writing step. Writing in Kanji cannot be done arbitrarily. It has its own writing procedure. As an example, in writing 三 "san", it starts from the top part and is continued to the middlepart then the bottom part. Thus, Writing Kanji cannot be done randomly. It has to be in order based on the example above. In addition, Hitsujunis not only appliedin writing Kanji but also in Hiragana and Katakana.

Iwabuchi (Sudjianto, 2009: 66) explains that to unify the Hitsujun on Kanji especially in the field of education, Mambushoproposed the HitsujunShidou no Tebiki in 1985. It is the sequence principles of writing in Kanji. The principles are as follows.

a) Kanji is written from the top to the bottom, e.g三, 喜.

b) Kanji is written from the left to the right, e.g川, 例.

c) Yokokaku (horizontal straight lines) on Kanji that has the cross-like form is written first, e.g十, 大. However,

Yokokakuon Kanji田, 王 is written later.

d) Lines or streaks which are the center of the Kanji, e.g水, 小 are written first, except for streaks in Kanji火 and 性.

e) The outer line of Kanjiis written first, e.g国, 同じ, 司

f) The streak of Hidariharai (the left streak) is written first, e.g人, 文.

g) The streak of Tatekaku(the perpendicular line) which divides the other part of Kanji is written in the final sequence e.g車, 中. Letters such as 里, 重, and those which divide the top part or the bottom part of the Kanji are written from the top part of the Kanji then Tatekaku and finally the bottom part of the Kanji.

h) The streak of Yookaku which splits the rest of the Kanji is written in the last sequence, eg女, 子, 母.

Based on the previous explanation, it is analyzed that Kanji has certain rules inits writing. The rules are written in the HitsujunShidou no Tebiki as a reference in learning Kanji as well as a unification of the Kanji writing steps. Hitsujun is not only used in writing Kanji but also Hiragana and Katakana.

\section{METHOD}

This quantitative research used numbers as its data. This is in line withthe explanation proposed by Sugiyono (2013: 7) who states that a quantitative research is a research that uses numbers as data and analyzes them by using statistics. The numbers in this study were scores of the $5^{\text {th }}$ semester Japanese Education Study Program students' mastery.

This descriptive research applied the survey and case study design. The population was the students ofJapanese Education Study Programof UNP. 25 of them were chosen as the sample of the research. They were divided into 6 instrument test samples and 19 research samples. The sampling technique used was the purposive samplingin which"the samples are determined by using certain consideration" (Sutedi; 2009: 181). This is in accordance with the opinion of Sugiyono (2013: 81) who states that when the population is large and it is impossible for the researcherto do research to all of them due to limited fund, energy and time, then she/he is allowed to take samples from the total number of the population. What is learned from the sample will be generalized to the population. Thus, the samples taken have to be representative.

Data analysis was aimed at determining the mastery level of students' Kanjiwriting based on the research questions in the formulation of the problem in this study. The obtained data were analyzed in these following steps.

First, students' Kanji writing mastery was assessed by using a test. Their scores were analyzed by using indicators seen in the table 1 below.

Table 1. Students' Score

\begin{tabular}{|l|l|l|l|l|l|l|l|l|l|}
\hline \multirow{2}{*}{ No. } & Sample & \multicolumn{7}{|c|}{ Question Number } & \multirow{2}{*}{ Total score } \\
\cline { 3 - 9 } & & $\mathbf{1}$ & $\mathbf{2}$ & $\ldots$ & $\ldots$ & $\ldots$ & $\ldots$ & $\mathbf{1 0}$ & \\
\hline 1. & & & & & & & & & \\
\hline 2. & & & & & & & & & \\
\hline
\end{tabular}

Notes:

The range of scores are from 0 to 2 .

Score 2: both writing steps and forms are correct.

Score 1: the writing steps are incorrect while the forms are correct. 
Score 0: both writing steps and forms are incorrect.

Second, the students' final scores were calculated using the following formula:

$\mathrm{n}=($ ( correct score $) \times 100($ Sukestiyarno, 2009: 64) ( score)

Third, their mean score were calculated using the following formula:

$M=\Sigma \underline{F}_{\underline{X}}($ Abdurahman and Ratna (2003: 270))

$\mathrm{N}$

Notes:

M: mean

$\mathrm{F}_{\mathrm{x}}$ : the total number of students' scores

$\mathrm{N}$ : the total number of samples

Fourth, the students' mastery was classified based on the table 2 below:

Table II. Table of Conversion List

\begin{tabular}{|c|c|c|c|}
\hline No. & Mastery Level & Scale & Conversion \\
\hline 1 & $96 \%-100 \%$ & 10 & Excellent \\
\hline 2 & $86 \%-95 \%$ & 9 & Very Good \\
\hline 3 & $76 \%-85 \%$ & 8 & Good \\
\hline 4 & $66 \%-75 \%$ & 7 & Fairly Good \\
\hline 5 & $56 \%-65 \%$ & 6 & Satisfactory \\
\hline 6 & $46 \%-55 \%$ & 5 & Quite Satisfactory \\
\hline 7 & $36 \%-45 \%$ & 4 & Poor \\
\hline 8 & $26 \%-35 \%$ & 3 & Very Poor \\
\hline 9 & $16 \%-25 \%$ & 2 & Extremely Poor \\
\hline 10 & $0 \%-15 \%$ & 1 & Fail \\
\hline
\end{tabular}

(Abdurahman andRatna, 2003:265)

Fifth, a histogram of the students' Kanji writing mastery was made. Finally, the results of data analysis were discussed and conclusions were drawn.

\section{FINDING AND DISCUSSION}

The following table described the scores of the $5^{\text {th }}$ semester students' Kanji writing mastery at Japanese Education Study Program of UNP.

Table III. Students' Scores

\begin{tabular}{|c|c|c|c|c|}
\hline No. & Score $(\mathbf{X})$ & Classification & Frequency(F) & FX \\
\hline 1. & 85 & Good & 1 & 85 \\
\hline 2. & 75 & Fairly Good & 1 & 75 \\
\hline 3. & 74 & Fairly Good & 1 & 74 \\
\hline 4. & 65 & Satisfactory & 2 & 130 \\
\hline 5. & 64 & Satisfactory & 1 & 64 \\
\hline 6. & 63 & Satisfactory & 3 & 189 \\
\hline 7. & 59 & Satisfactory & 2 & 118 \\
\hline 8. & 55 & Quite Satisfactory & 2 & 110 \\
\hline 9. & 54 & Quite Satisfactory & 2 & 108 \\
\hline 10. & 53 & Quite Satisfactory & 1 & 53 \\
\hline 11. & 45 & Poor & 2 & 90 \\
\hline 12 & 44 & Poor & 1 & 44 \\
\hline \multicolumn{2}{|r|}{ Total } & & 19 & 1140 \\
\hline
\end{tabular}

The students'Kanji writing mastery was described as follows. First, there was only one student who got a "good"grade. Second, there were two of them who got the "fairly good" grade. Third, 8 of them were classified into the "satisfactory" classification. Fourth, 5 students got the "quite satisfactory" grade. Finally, 3 of them were categorized as "poor".

The students' meanscore was analyzed by using the formula of $\mathrm{M}=\Sigma \underline{F_{X}}$, in which $\mathrm{M}=\underline{1140}=63.3$. 
$\mathrm{N}$

18

To sum up, from the mean score, it is found that the students' Kanji writing mastery was classified into the "satisfactory" classification.

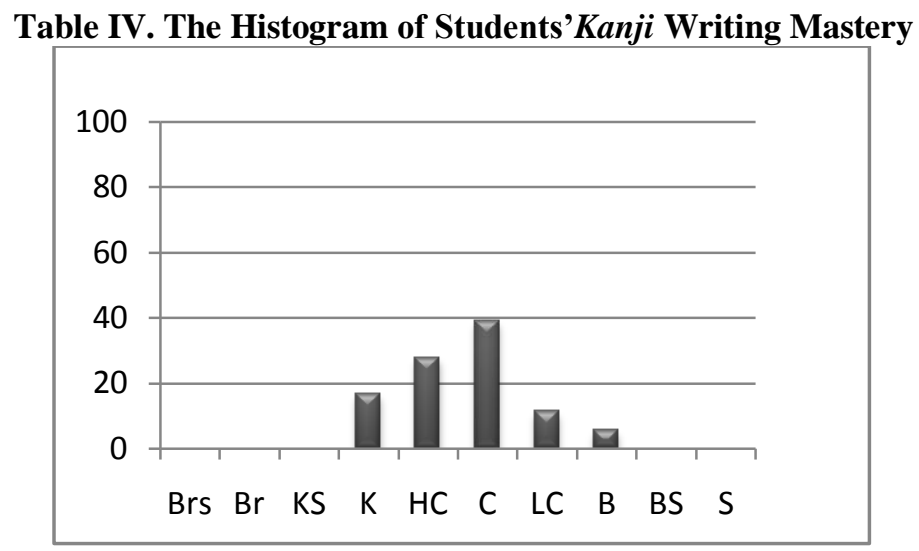

Notes:

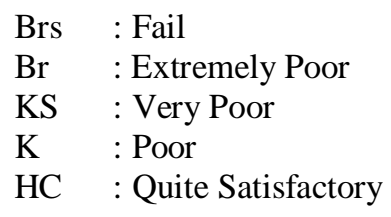

$\begin{array}{ll}\text { C } & \text { : Satisfactory } \\ \text { LC } & \text { : Fairly Good } \\ \text { B } & \text { : Good } \\ \text { BS } & \text { : Very Good } \\ \text { S } & \text { : Excellent }\end{array}$

From the histogram, it is analyzed that the students' Kanji mastery was divided into 5 classifications. First, the "good"classification was 5.56\%. Second, the "fairly good"classification was $11.11 \%$. Third, the "satisfactory"classification was $38.89 \%$. Fourth, the "quite satisfactory" was $27.78 \%$. Finally, the "poor"classification was $16.66 \%$. The "satisfactory" classification was at the highest frequency with the percentage of $38.89 \%$ while the "good" classification was at the lowest frequency with the percentage of $5.56 \%$.

Based on the results of the test and data analysis of the students' Kanji writing mastery, it is found that the mean score of the students' mastery was 63.33 which was in the "satisfactory" classification. Errors made by the students need to be observed carefully. Most of them made errors in determining the Hitsujun, Bushu and KakusuuKanjibased on the rules set inthe TouyouKanji. Since the errors are not complied with the Hitsujun and KakusuuKanji,it willbe difficult for the students to find outthe use of Kanjiin the Kanjidictionary. When the Kanji forms are correct and the Hitsujun and Kakusuuof the Kanji writingare incorrect, then the Kanjicharacters that want to be written will not be found since they are not in accordance with the rules set on the TouyouKanji.

Unfortunately, those errors were not only made by the $5^{\text {th }}$ semester students of Japanese Education Study Programof UNP but also by other Japanese learners. It happens since there are many characters in Kanji and each of them has distinctive Bushu, Hitsujun and Kakusuuwhich make it difficult for the Japanese learnersto memorize them. Sudjianto (2009: 57) mentions that one problem faced by the Japanese learners in learning Kanji is the numbers of Kanji that have to be mastered. Thus, it is difficult for them to memorize the forms and their pronunciation.

\section{CONCLUSION AND RECOMMENDATION}

Some conclusions can be drawnbased on the research results. The students' Kanji writing mastery was in the "satisfactory" classification with the mean score of 63.33. The problems faced by them in the mastery of Kanjiwriting are related to the determination of Bushu, Hitsujun and Kakusuuso that the writing of Kanji is not based on the rules set on the TouyouKanji. The errors are caused by the large numbers of Kanji that have to be mastered. Each of the characters has different Bushu, Hitsujun and Kakusuuso that it is difficult for the students to memorize them. Those difficulties do not only occur for learners who do not have a cultural background about Kanji. They also happen for those who have the cultural background about Kanji such as China, Korea, and Taiwan. Although they use the same characters and meanings, the way of pronouncing them is different. Therefore, pronunciation is one of the difficulties for the learners who have the background as well as those who do not have it.

Based on the conclusions, it is expected that there will be a good learning method that can help the students in improving theirwriting masteryespecially the writing of Bushu, Hitsujun and KakusuuKanji. 


\section{References}

Abdurahman dan Ellya Ratna. ((2003). Evaluasi Pembelajaran Bahasa dan Sastra Indonesia. Padang: UNP Perss. Arikunto, Suharsimi. (2010). Manajemen Penelitian. Jakarta: Rineka Cipta Arikunto, Suharsimi. (2010). Prosedur Penelitian Suatu Pendekatan Praktik. Jakarta: Rineka Cipta Nihongo Kyouiku Gakkai. (1990).Nihongo Kyoiku Handobukku. Tokyou: Taishuukanshoten.

Mangerongkonda, Ivond. (2013). AnalisisKesalahanPenggunaan Kata KerjaKausatif (ShiekiDoushi) dalamKalimatBahasaJepang. Skripsi. Semarang: FBS, UNES.

Sudjana. (2005). Metoda Statistika. Bandung: Tarsito.

Sudjianto\& Ahmad Dahidi. (2009). PengantarLinguistikBahasaJepang. Jakarta:Oriental.

Sugiyono. (2013). MetodePenelitianKuantitatifKualitatif R\&D. Bandung:Alfabeta.

Suryabrata, Sumardi. (2010). Metodologi Penelitian. Jakarta: Rajawali Pers.

Sutedi, Dedi. (2009). Penelitian Pendidikan Bahasa Jepang. Bandung: Upi Press

Sutedi, Dedi. (2003). Dasar-DasarLinguistikBahasaJepang. Bandung: HumanioraUtama Press.

Takehiko, Kandouri. (1990). Kodomo Kanji Jiten. Toukyou: Sanshaei

Yusuf, Muri. (2005). Dasar-DasardanTeknikEvaluasiPendidikanPilarPenyediaInformasidanKegiatanPenjamin Serta PenetapanMutuPendidikanTerhadapBerbagaiKomponenPendidikan. UNP Pers: Padang.

Zalman, Hendri. (2012). Kosa Kata BahasaJepang. Padang: FBS Press. 